\title{
Biocontrol Traits of Pseudomonas spp. Are Regulated by Phase Variation
}

\author{
Daan van den Broek, Thomas F. C. Chin-A-Woeng, Kevin Eijkemans, Ine H. M. Mulders, Guido V. \\ Bloemberg, and Ben J. J. Lugtenberg
}

Leiden University, Institute of Biology Leiden, Clusius Laboratory, Wassenaarseweg 64, 2333 AL Leiden, The Netherlands

Submitted 24 February 2003. Accepted 7 July 2003.

Of 214 Pseudomonas strains isolated from maize rhizosphere, 46 turned out to be antagonistic, of which 43 displayed clear colony phase variation. The latter strains formed both opaque and translucent colonies, designated as phase I and phase II, respectively. It appeared that important biocontrol traits, such as motility and the production of antifungal metabolites, proteases, lipases, chitinases, and biosurfactants, are correlated with phase I morphology and are absent in bacteria with phase II morphology. From a Tn5luxAB transposon library of Pseudomonas sp. strain PCL1171 phase I cells, two mutants exhibiting stable expression of phase II had insertions in gacS. A third mutant, which showed an increased colony phase variation frequency was mutated in mutS. Inoculation of wheat seeds with PCL1171 bacteria of phase I morphology resulted in efficient suppression of take-all disease, whereas disease suppression was absent with phase II bacteria. Neither the gacS nor the mutS mutant was able to suppress take-all, but biocontrol activity was restored after genetic complementation of these mutants. Furthermore, in a number of cases, complementation by gacS of wild-type phase II sectors to phase I phenotype could be shown. A PCL1171 phase I mutant defective in antagonistic activity appeared to have a mutation in a gene encoding a lipopeptide synthetase homologue and had lost its biocontrol activity, suggesting that biocontrol by strain PCL1171 is dependent on the production of a lipopeptide. Our results show that colony phase variation plays a regulatory role in biocontrol by Pseudomonas bacteria by influencing the expression of major biocontrol traits and that the gacS and mutS genes play a role in the colony phase variation process. Therefore phase variation not only plays a role in escaping animal defense but it also appears to play a much broader and vital role in the ecology of bacteria producing exoenzymes, antibiotics, and other secondary metabolites.

Additional keywords: Gaeumannomyces graminis pv. tritici.

In commercial agriculture, crop protection against phytopathogens relies heavily on chemical pesticides. There is a growing concern for negative health and environmental effects of such pesticides. For example, the European Union has decided that $60 \%$ of the chemical pesticides that were allowed in 1996 will be banned in 2003. Therefore, alternatives for the use of chemicals

Corresponding author: B. J. J. Lugtenberg; Telephone: +31715275063; Fax.: +31715275088; E-mail: lugtenberg@ rulbim.leidenuniv.nl.

Nucleotide sequence data reported are available in the GenBank database under accession numbers AY236957, AY236958, and AY236959 for gacS, mutS, and 16s rDNA, respectively, of Pseudomonas sp. strain PCL1171. are needed. The use of genetically engineered disease-resistant plants is perceived poorly by the public, especially in Europe. Therefore, the use of microorganisms to control plant pathogens is the most attractive alternative. So far however, success in the field is limited due to variable results.

The control of phytopathogenic fungi by biocontrol microbes depends on a wide variety of traits, such as the production of antifungal metabolites (AFM) (Buchenauer 1998; Chin-A-Woeng et al. 1998; Keel et al. 1990; Maurhofer et al. 1994; Raaijmakers and Weller 1998; Thomashow and Weller 1988), production of exoenzymes such as proteases, lipases, chitinases, and glucanases (Buchenauer 1998; Dunlap et al. 1998; Trejo et al. 1998), production of hydrogen cyanide ( $\mathrm{HCN}$ ) (Voisard et al. 1989), production of siderophores (Leong 1986), of biosurfactants (Stanghellini and Miller 1997), and competitive root colonization (Chin-A-Woeng et al. 2000; Lugtenberg et al. 2001). Previous results indicated that mutation of a xerC/sss homologue from the efficiently root-colonizing $P$. fluorescens WCS365 resulted in a decrease in the frequency of colony phase variation and a severe decrease of its competitive root-tip colonizing abilities (Dekkers et al. 1998, 2000). The xerC/sss product has been reported to be involved in DNA rearrangements (Colloms et al. 1990).

Phase variation is a regulatory process by which bacteria undergo frequent and (often) reversible phenotypic changes resulting from genetic alterations in specific loci of their genome. Phase variation is based on structural changes at the DNA level and results in subpopulations of bacteria, as is often demonstrated by the presence of distinct morphological phases between colonies or within a colony (Dybvig 1993; Henderson et al. 1999). In general, phase variation, thought of as a random event, occurs at frequencies of $>10^{-5}$ per generation (Henderson et al. 1999). Phase variation, as a regulatory system, can influence the production of diverse traits such as the production of proteases and lipases (Chabeaud et al. 2001), pili (Meyer et al. 1990), outer membrane proteins (Meyer et al. 1990), fimbriae (Abraham et al. 1985), surface lipoproteins (Rosengarten and Wise 1990), flagella (Josenhans et al. 2000), and other surface-exposed antigenic structures (Dybvig 1993; Henderson et al. 1999).

The finding in our group that phase variation can negatively influence competitive root-tip colonization (Dekkers et al. 1998; Dekkers et al. 2000) and, therefore, biocontrol (Chin-AWoeng et al. 2000) has prompted us to study the influence of colony phase variation on other biocontrol traits.

\section{RESULTS}

Selection of antagonistic Pseudomonas spp. strains that undergo phase variation.

A collection of 214 Pseudomonas strains was isolated from the rhizosphere of maize plants from an agricultural field in 
Totontepec Mixe, Oaxaca, Mexico. They were preliminary characterized as pseudomonads based on their growth on Pseudomonas isolation medium, colony morphology, and amplified ribosomal DNA restriction analysis (ARDRA). Using an antifungal activity plate assay (Geels and Schippers 1983), it was shown that $46(21 \%)$ of the strains inhibited the growth of Gaeumannomyces graminis pv. tritici R3-11A, Fusarium oxysporum f. sp. radicis-lycopersici, Rhizoctonia solani, and Rosellinia necatrix. Another 33 strains (15\%) showed slight antagonistic activity, i.e., the colonies were not overgrown by the fungus. The remaining 135 strains (63\%) did not exhibit activity toward the fungal species tested.

Forty-three (93\%) of the 46 selected strongly antagonistic strains showed colony phase variation, as judged after 4 days of growth on King's medium $\mathrm{B}(\mathrm{KB})$ agar at $28^{\circ} \mathrm{C}$. Two morphologically different colony types were found for all strains. Colonies referred to as phase I are thick and opaque (the majority of colonies in Figure 1A and B), whereas those of phase II are flat and translucent (Fig. 1C). After separation of the two phases by restreaking on $\mathrm{KB}$ agar and subsequent growth for 2 days at $28^{\circ} \mathrm{C}$, roughly three classes with distinct but somewhat fluctuating frequencies of phase variation could be distinguished. Fluctuating frequencies of phase variation could be distinguished in liquid culture with average frequencies of $>9.0$ $\times 10^{-2}$, around $10^{-3}$, and $<1.5 \times 10^{-4}$ switches per generation. For the latter class, consisting of strains PCL1152, PCL1157,
PCL1159, PCL1166, PCL1169, PCL1177, PCL1182, and PCL1184, both colony types can be maintained separately. A low frequency of switching $\left(<5.0 \times 10^{-4}\right)$ was observed from phase I to phase II, whereas a slightly higher switching frequency (around $10^{-3}$ ) was observed from phase II back to phase I. PCL1171 and PCL1173 exhibit a low frequency of switching $\left(<5.0 \times 10^{-4}\right)$ from phase I to phase II. However, a high frequency $\left(>9.0 \times 10^{-2}\right)$ for the reverse switch was observed, since restreaking of phase II colonies with a single phase appearance immediately resulted in phase I colonies out of which phase II sectors are again formed after two days of growth. For the most unstable strains, PCL1155, PCL1161, PCL1163, PCL1175, and PCL1180, both phases are unstable, and restreaking of one of the phases always resulted in a mixture of phase I and phase II colonies. Based on differences in colony morphology and distinct frequencies of phase variation, 15 strains were selected (Table 1) for characterization of surface characteristics and the expression of biocontrol traits.

\section{Biocontrol traits expressed in different phases.}

Each of the 15 selected strains showed a different lipopolysacharide (LPS) ladder pattern on SDS-PAGE (sodium dodecyl sulfate-polyacrylamide gel electrophoresis), but no difference in LPS patterns were found between the two colony phases of a single strain (data not shown). One of the strains, Pseudomonas sp. strain PCL1171, was examined for differences in cell
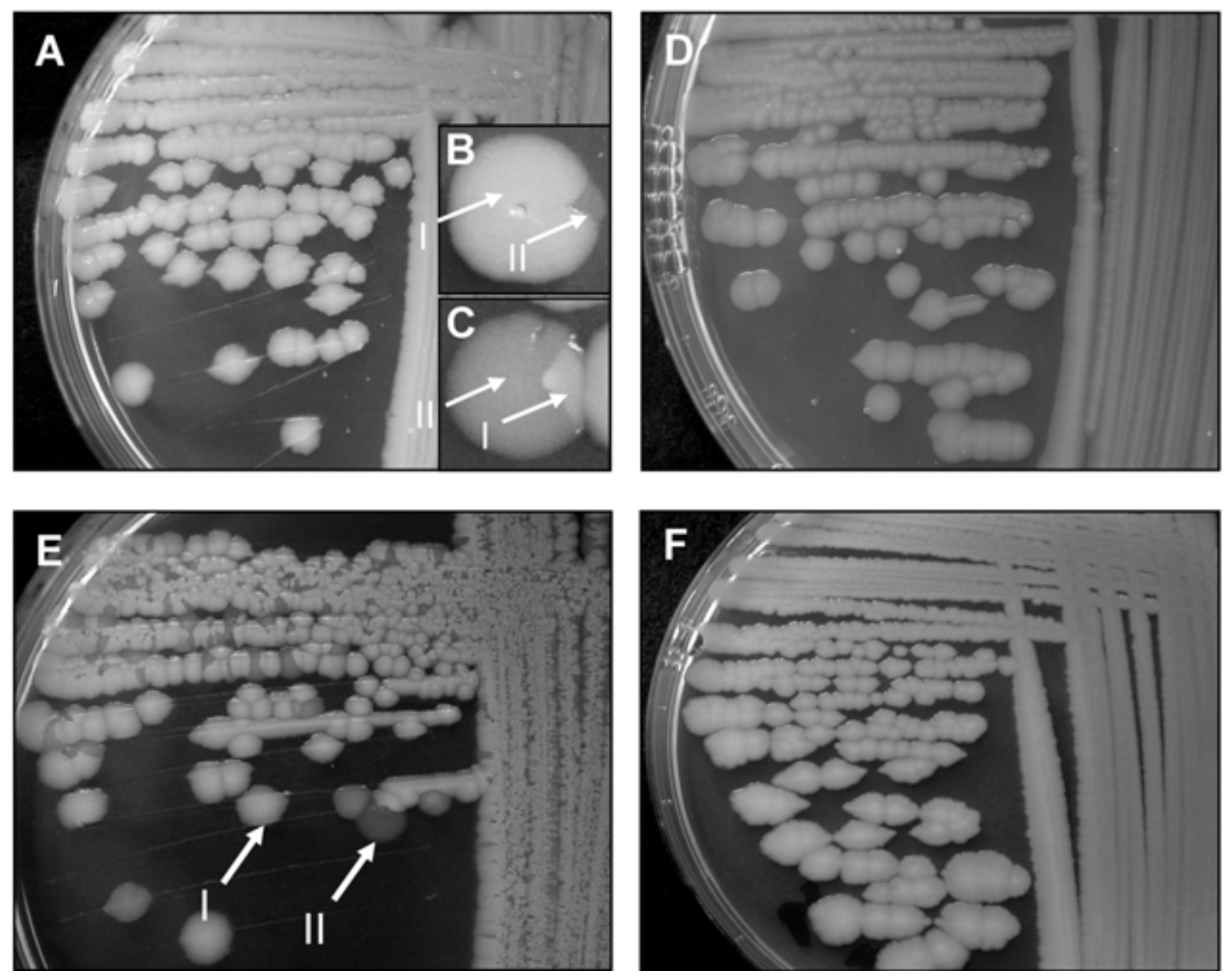

Fig. 1. Colony phase variation of PCL1171 and its mutants. A, Wild-type PCL1171, in which colonies with a phase I morphology are dominant; B, enlargement of a single colony of this strain, in which phase II appears as a sector; $\mathbf{C}$, enlargement of a single colony of this strain, in which a phase I sector appears; D, stable phase II colony morphology of PCL1572 (Tn5luxAB::gacS); E, colony morphology of PCL1555 (Tn5luxAB::mutS), in which the frequency of colony phase variation is increased; and F, colony morphology of PCL1556 (Tn5luxAB::mutS) complemented by pMCS5-mutS, which decreases the frequency of colony phase variation of the mutant to wild-type levels. The arrows indicate phase I (I) and phase II (II) colonies, respectively. 
envelope proteins between its two phases. SDS-PAGE analysis showed that proteins with apparent molecular masses of 5 and $30 \mathrm{kDa}$ were enhanced in phase I, whereas proteins with apparent molecular masses of 12,72 , and $84 \mathrm{kDa}$ were enhanced in phase II cells (Fig. 2). The ability of PCL1171 cells of the separate phases to attach to roots of wheat or tomato was analyzed in a time course but no differences were observed. Both phase I and phase II bacteria were tested on motility plates. Overnight incubation of the bacteria resulted in a clear motility circle for phase II bacteria and in an irregular movement of the bacteria over the plate for phase I bacteria (Fig. 3).

Phase I and phase II bacteria of the 15 selected strains were tested in a plate assay for inhibition of the growth of the phytopathogenic fungi G. graminis pv. tritici, Fusarium oxysporum f. sp. radicis-lycopersici, Rhizoctonia solani, and Rosellinia necatrix. Only phase I bacteria inhibited growth of the fungal species tested. Furthermore, the production of chitinase and biosurfactant was also found to be correlated with phase I morphology for all 15 strains. Protease and lipase were primarily produced by bacteria with a phase I morphology, although, for seven strains, phase II bacteria still produce protease or lipase activities, or both. None of the selected strains produced hydrogen cyanide, cellulase, or $\beta$-glucanase (Table 2 ).

\section{Preliminary genetic characterization of colony phase variation by strain PCL1171.}

One of the 15 selected Pseudomonas strains, strain PCL1171, was chosen for preliminary genetic characterization of the colony phase variation phenomenon. This choice was based on the strain's relatively stable expression of phase I morphology on $\mathrm{KB}$ agar plates. Phase II sectors were only found after approximately two days at the border of PCL1171 phase I colonies (Fig. 1A and B). Later, we observed that restreaking of these phase II sectors coincided with a high frequency of switching back to phase I phenotype, resulting in mainly phase I morphology on agar medium. The strain was further identified using polymerase chain reaction (PCR) amplification and subsequent sequencing of the $16 \mathrm{~S}$ rDNA of

Table 1. Microbial strains and plasmids

\begin{tabular}{|c|c|c|}
\hline Strains and plasmids & Characteristics & Reference or source \\
\hline \multicolumn{3}{|l|}{ Bacterial strains } \\
\hline PCL1171 & $\begin{array}{l}\text { Antagonistic Pseudomonas strain isolated from the rhizosphere of maize from Mexican } \\
\text { agricultural fields. Colony morphology varies between two distinct phases, defined as phases I } \\
\text { (opaque) and II (translucent). Model strain chosen for genetic studies }\end{array}$ & This study \\
\hline PCL1152, PCL1155, & Other antagonistic Pseudomonas strains isolated from the rhizosphere of maize from Mexican & This study \\
\hline PCL1157, PCL1159, & agricultural fields. Colony morphologies vary with different frequencies between two distinct & \\
\hline PCL1161, PCL1163, & phases defined as phase I and phase II & \\
\hline PCL1166, PCL1169, & & \\
\hline PCL1173, PCL1175, & & \\
\hline PCL1177, PCL1180, & & \\
\hline PCL1182, PCL1184 & & \\
\hline PCL1572 & $\begin{array}{l}\text { Derivative of PCL1171 in which a promoterless Tn } 5 \text { luxAB transposon is inserted into a gacS } \\
\text { homologue }\end{array}$ & This study \\
\hline PCL1563 & $\begin{array}{l}\text { Derivative of PCL1171 in which a promoterless Tn } 5 \operatorname{lux} A B \text { transposon is inserted into a gacS } \\
\text { homologue }\end{array}$ & This study \\
\hline PCL1564 & PCL1572 complemented with pMP6562 (pME6010-gacS) & This study \\
\hline PCL1555 & $\begin{array}{l}\text { Derivative of PCL1171 in which a promoterless Tn } 5 \text { lux } A B \text { transposon is inserted into a mutS } \\
\text { homologue }\end{array}$ & This study \\
\hline PCL1556 & PCL1555 complemented with pMCS5-mutS & This study \\
\hline PCL1391 & $\begin{array}{l}\text { Pseudomonas chlororaphis. Efficient biocontrol strain and good competitive colonizer of tomato } \\
\text { roots, which produces phenazine-1-carboxamide. }\end{array}$ & Chin-A-Woeng et al. 1998 \\
\hline PCL1666 & $\begin{array}{l}\text { Derivate of PCL1171 in which a promoterless Tn } 5 \text { luxAB transposon is inserted into a lipopeptide } \\
\text { synthetase homologue }\end{array}$ & This study \\
\hline PCL1656 & $\begin{array}{l}\text { Derivate of PCL1171 in which a promoterless Tn } 5 \operatorname{lux} A B \text { transposon is inserted into the thiolation } \\
\text { domain of a lipopeptide synthetase homologue }\end{array}$ & This study \\
\hline PCL1663 & $\begin{array}{l}\text { Derivate of PCL1171 in which a promoterless Tn } 5 \operatorname{lux} A B \text { transposon is inserted into a condensation } \\
\text { domain of a lipopeptide synthetase homologue }\end{array}$ & This study \\
\hline PCL1660 & $\begin{array}{l}\text { Derivate of PCL1171 in which a promoterless Tn } 5 \operatorname{lux} A B \text { transposon is inserted into a region } \\
\text { preceding a adenylation domain of a lipopeptide synthetase homologue }\end{array}$ & This study \\
\hline DH5 $\alpha$ & E. coli endA1 gyrSA96 $h r d R 17(\mathrm{rK}-\mathrm{mK}-)$ supE44 recA1; general purpose $E$. coli host strain & $\begin{array}{l}\text { Boyer and Rouland- } \\
\text { Dussoix } 1969\end{array}$ \\
\hline \multicolumn{3}{|l|}{ Fungal strains } \\
\hline ZUM2407 & Fusarium oxysporum $\mathrm{f}$. sp. radicis-lycopersici; causes tomato foot and root rot & $\begin{array}{l}\text { IPO-DLO Wageningen, } \\
\text { The Netherlands }\end{array}$ \\
\hline 3R4FNA & Rhizoctonia solani; causes damping-off and fruit rot & $\begin{array}{l}\text { IPO-DLO Wageningen, } \\
\text { The Netherlands }\end{array}$ \\
\hline 400 & Rosellinia necatrix; causes white root rot or Rosellinia root rot in a wide range of host plants & Pérez-Jiménez et al. 1997 \\
\hline $\mathrm{R} 3-11 \mathrm{~A}$ & Gaeumannomyces graminis pv. tritici; causes take-all disease of wheat and of other cereals & $\begin{array}{l}\text { Raaijmakers and Weller } \\
1998\end{array}$ \\
\hline \multicolumn{3}{|l|}{ Plasmids } \\
\hline pRL1063a & Plasmid harboring a promoterless $\operatorname{Tn} 5 \operatorname{lu} x A B$ transposon $\mathrm{Km}^{\mathrm{r}}$, and a p15A origin of replication & Wolk et al. 1991 \\
\hline pGEM-T Easy & Vector system for cloning PCR products, $\mathrm{Cb}^{\mathrm{r}}$ & $\begin{array}{l}\text { Promega, Madison, WI, } \\
\text { U.S.A. }\end{array}$ \\
\hline pME6010 & $\begin{array}{l}\text { E. coli/Pseudomonas shuttle vector, stably maintained in Pseudomonas species, with an estimated } \\
\text { copy number of } 4 \text { to } 8, \mathrm{Tc}^{\mathrm{r}}\end{array}$ & Heeb et al. 2000 \\
\hline pMP6562 & $\begin{array}{l}\text { pME6010 harboring a 3.2-kb PCR product from strain PCL1171, which contains the gacS } \\
\text { homologue from PCL1171,Tc }{ }^{\mathrm{r}}\end{array}$ & This study \\
\hline pMP5565 & $\begin{array}{l}\text { pME6010 harboring a } 1.2 \mathrm{~kb} \text { PCR product from Pseudomonas sp. strain PCL1446, which contains } \\
\text { a gacA homologue }\end{array}$ & $\begin{array}{l}\text { Kuiper et al., } \\
\text { unpublished data }\end{array}$ \\
\hline pMCS5-mutS & pBBR1 MCS-5 containing the mutS gene from $P$. aeruginosa, $\mathrm{Gm}^{\mathrm{r}}$ & Pezza et al. 2002 \\
\hline
\end{tabular}


phase I and phase II colonies, which yielded identical sequences. This sequence data has been submitted to GenBank under accession number AY236959. Comparison of these sequences with those in the GenBank database revealed similarity with sequences of Pseudomonas sp. RNA group I, which includes $P$. aeruginosa, $P$. chlororaphis, $P$. fluorescens biovars, and $P$. putida. Based on $16 \mathrm{~S}$ rDNA sequence, similarity (up to $99 \%$ identity) was found to a large group of $P$. tolaasii strains (with $100 \%$ identity). However, this $16 \mathrm{~S}$ rDNA sequence clearly branches off from these Pseudomonas species (data not shown) and is therefore considered to be closely related to $P$. tolaasii species.

A Tn5luxAB transposon library of phase I of strain PCL1171 was constructed. Mutants that exhibited a phase-locked colony morphology or an altered phase variation frequency were selected. Three mutants were selected out of 900 transposons. Two of these mutants, strains PCL1563 and PCL1572, appeared to be locked in a phase II colony morphology (Fig. 1D). Consistent with what we found for phase II cells of wild-type strain PCL1171, the mutants PCL1563 and PCL1572 did not produce protease, lipase, or biosurfactant and were not antagonistic (data not shown).

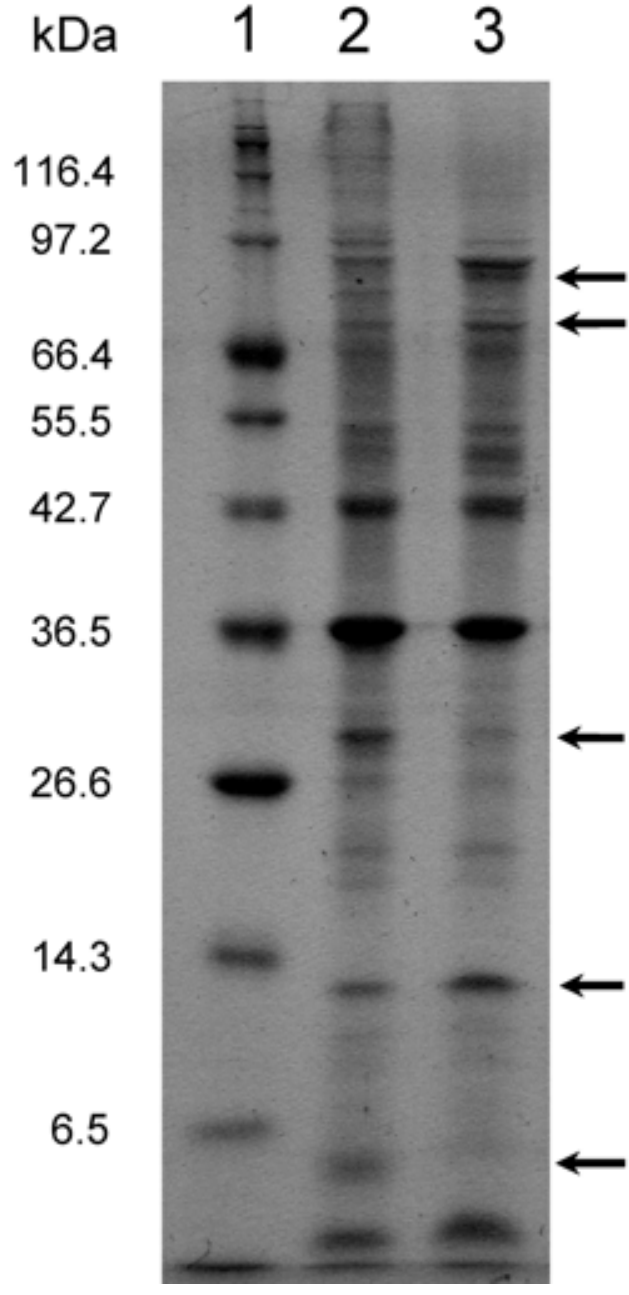

Fig. 2. Sodium dodecyl sulfate-polyacrylamide gel electrophoresis (SDSPAGE) analysis of cell envelope proteins of phase I and phase II bacteria of strain PCL1171. SDS-PAGE gel of the cell envelope proteins isolated from colonies of PCL1171. Lane 1, protein markers (sizes indicated in $\mathrm{kDa}$ on the left); lane 2, cell envelope proteins expressed by phase I cells; and lane 3 , cell envelope proteins expressed by phase II cells (arrows indicate differences in expression of proteins between phase I and phase II cells). Clear differences in protein expression were observed for proteins with apparent molecular masses of 5, 12, 30, 72, and $84 \mathrm{kDa}$.
Sequencing of the regions flanking the Tn 5 lux $A B$ transposons of mutants PCL1563 and PCL1572 revealed that their transposons had inserted at different positions in the same gene (Fig. 4A). The mutated gene, predicted to encode a protein of 918 amino acids (aa), showed highest homology (82\% identity and $89 \%$ similarity at the amino acid level) to the $\mathrm{gacS}$ gene product of $P$. chlororaphis (GenBank accession number AAF06332) (Fig. 4A). Downstream of $g a c S$, an open reading frame (ORF) transcribed in the same direction as gacS, was revealed, the predicted protein product of which shows $65 \%$ identity and $74 \%$ similarity at the amino acid level to D-lactate dehydrogenase of $P$. aeruginosa (PA0927) (Fig. 4A). Upstream of the gacS gene an ORF transcribed in the opposite direction was predicted to encode a protein with $50 \%$ identity and $70 \%$ similarity at amino acid level

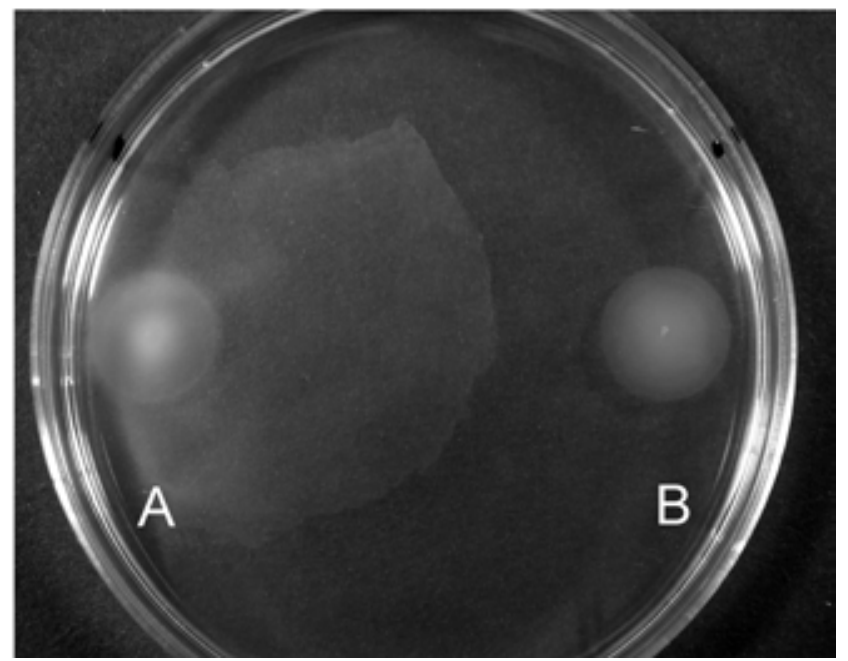

Fig. 3. Motility of PCL1171 phase I and phase II cells. Cells of PCL1171 $\mathbf{A}$, phase I and $\mathbf{B}$, phase II were inoculated on $1 / 20$ King's medium B agar and were grown overnight at $28^{\circ} \mathrm{C}$.
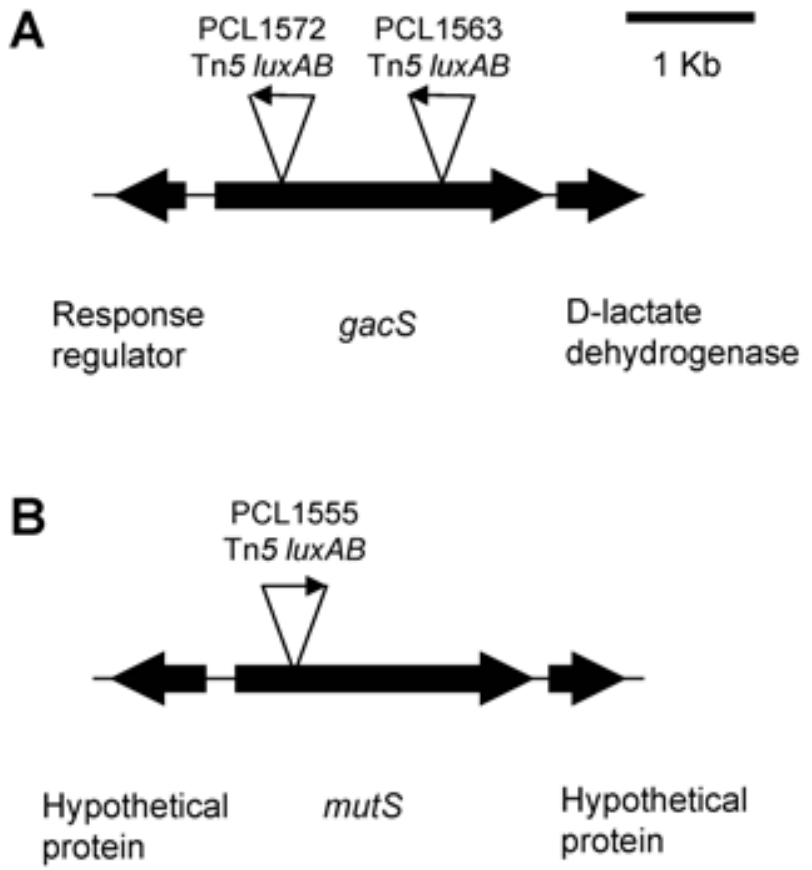

Fig. 4. Schematic representation of the chromosomal regions of PCL1171 surrounding the transposon insertions of mutants A, PCL1572 (gacS::Tn5luxAB) and PCL1563 (gacS::Tn5luxAB) and of B, PCL1555 (mutS::Tn5luxAB). The arrows of the indicated genes and transposons show the direction of transcription. 
to a response regulator of a two-component regulatory system (PA0929) (Fig. 4A). For complementation, a PCR product was constructed, containing the complete gacS homologue, including 390 bp upstream of the ATG to include the promoter region as well as 230 bp downstream of the stop codon, which includes a fragment of $169 \mathrm{bp}$ of D-lactate dehydrogenase. This PCR fragment, cloned into pME6010 (estimated copy number 4 to 8) resulting in pMP6562, restored phase variation in strains PCL1563 and PCL1572 to the wild-type level. In addition, PCL1157, PCL1182, and PCL1184 were used to test whether a spontaneous phase II phenotype can be based on a gacS mutation. Phase II bacteria from strains PCL1157, PCL1182, and PCL1184 could be (partially) complemented using pMP6562. A mixture of phase I and phase II colonies was obtained on plate. Complementation using pMP5565 harboring a gacA homologue from Pseudomonas sp. strain PCL1446 resulted in a mixture of phase I and phase II colonies (data not shown). Only phase II colonies were obtained after transformation of the empty parental vector.

The third mutant, strain PCL1555, displayed an increased switching frequency between phases I and II in comparison with the wild type (Fig. 1E), in such a way that neither of the phases could be obtained as colonies with a single phase appearance.

Sequencing of the flanking regions of the Tn5 insertion in PCL1555 showed that the transposon had inserted in a gene encoding a protein of 865 aa with $85 \%$ identity and $91 \%$ similarity at the amino acid level to the $m u t S$ gene product of $P$. aeruginosa (GenBank accession number AE004782), which was therefore designated $m u t S$ (Fig. 4B). Sequencing downstream of the $m u t S$ gene revealed an ORF transcribed in the same direction, the predicted protein product of which showed $92 \%$ identity and $94 \%$ similarity at the amino acid level to a hypothetical protein in $P$. fluorescens (GenBank accession number ZP_00085195) (Fig. 4B). Upstream of the mutS gene, an ORF transcribed in the opposite direction was predicted to encode a protein with $88 \%$ identity and $93 \%$ similarity at the amino acid level to a hypothetical protein of $P$. fluorescens (GenBank accession number ZP_00085197) (Fig. 4B). After transformation of PCL1555 with pMCS5-mutS, which contains the complete mutS gene and a downstream 203-bp fragment of ferrodoxin A from $P$. aeruginosa, the phase variation frequency of PCL1555 was restored to wild-type levels (Fig. 1E and F). The sequence data of gacS and mut $S$ has been submitted to the GenBank databases under accession numbers AY236957 and AY236958, respectively.

\section{Effect of colony phase variation}

on biocontrol ability of strain PCL1171.

Cells of the different colony phases of strain PCL1171 were tested for their biocontrol activity of wheat take-all caused by G. graminis pv. tritici. Inoculation of the wheat seeds with phase I bacteria resulted in a significant reduction of the dis- ease (Fig. 5A). PCL1171 phase I or phase II cells, tested in the absence of a pathogen, did not cause disease of wheat plants (data not shown). Inoculation of wheat seeds with phase II bacteria did not result in a statistically significant biocontrol, when
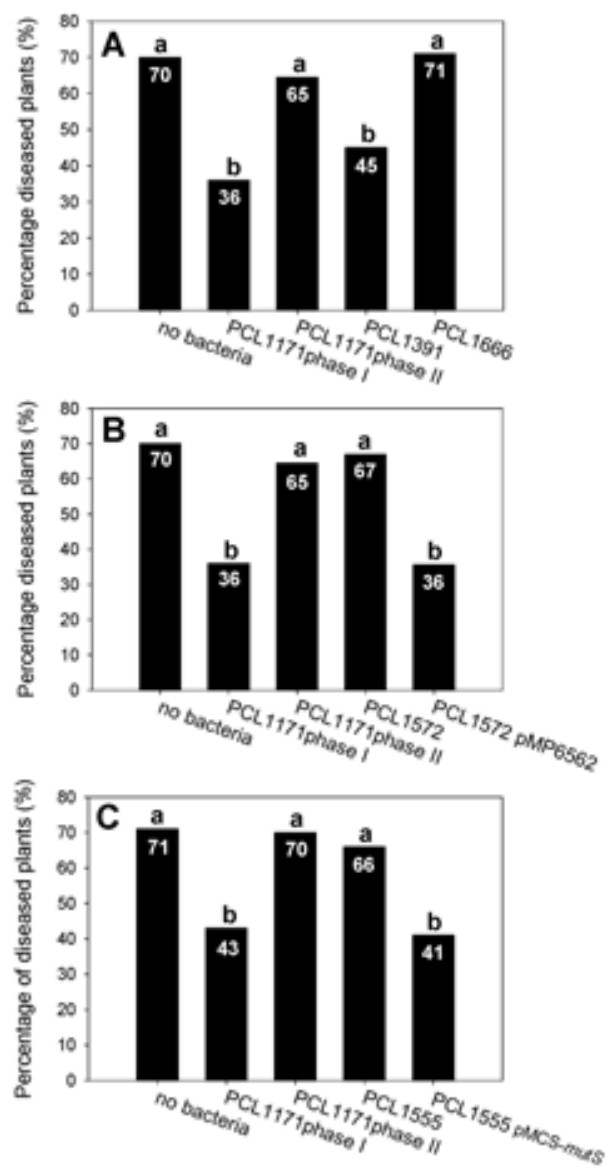

Fig. 5. Biocontrol of wheat take-all caused by Gaeumannomyces graminis pv. tritici. Wheat seeds were coated with bacteria and were grown in a 1:1 mixture of potting soil and quartz sand amended with $G$. graminis pv. tritici. Seeds were coated with cells of the indicated wild type or mutant or with cells of the indicated phase. Experiments using PCL1171 phase I and phase II cells to coat the seeds but without $G$. graminis pv. tritici did not result in diseased plants. The negative control consisted of seeds coated without bacteria. After 12 days of growth, the plants were scored for disease symptoms. For each strain, 108 plants were tested. Data were analyzed for significance using after arcsine square root transformations with analysis of variance, followed by a Fischer's least significant difference test $(p=0.05, n=12)$. Values with different letter indications denote a statistically significant difference. Similar results were obtained in a second experiment.

Table 2. Phase variation characteristics and biocontrol traits of 15 antagonistic Pseudomonas strains ${ }^{\mathrm{a}}$

\begin{tabular}{|c|c|c|c|c|c|c|}
\hline Group $^{b}$ & Morphology & $\mathbf{A F A}^{\mathrm{d}}$ & Biosurfactant & Chitinase & Protease & Lipase \\
\hline \multirow[t]{2}{*}{ A } & I & + & + & + & + & + \\
\hline & II & - & - & - & - & - \\
\hline \multirow[t]{2}{*}{ B } & I & + & + & + & + & + \\
\hline & II & - & - & - & + & - \\
\hline \multirow[t]{2}{*}{$\mathrm{C}$} & I & + & + & + & + & + \\
\hline & II & - & - & - & - & + \\
\hline \multirow[t]{2}{*}{$\mathrm{D}$} & I & + & + & + & + & + \\
\hline & II & - & - & - & + & + \\
\hline
\end{tabular}

${ }^{\text {a }}$ Isolated from the rhizosphere of maize plants from an agricultural field, Totontepec Mixe, Mexico.

${ }^{\mathrm{b}}$ Group A consists of strains PCL1155, PCL1157, PCL1169, PCL1171, PCL1177, PCL1180, PCL1182, and PCL1184, Group B consist of strains PCL1152, and PCL1163, Group C consists of strains PCL1159, and PCL1166, and group D consists of strains PCL1161, PCL1173, and PCL1175. None of the strains produced $\beta$-glucanase, cellulase, or hydrogen cyanide.

${ }^{c}$ Colony morphology, phase I (I) or phase II (II).

${ }^{\mathrm{d}}$ Antifungal activity (AFA) towards G. graminis pv. tritici R3-11A, F. oxysporum oxysporum f. sp. radicis-lycopersici, Rhizoctonia solani, and Rosellinia necatrix. 
compared with the untreated control seeds (Fig. 5A). Inoculation of the seeds using the well-described biocontrol strain $P$. chlororaphis PCL1391 resulted in a significant suppression of the disease (Fig. 5A).

\section{Role of antagonism}

\section{in biocontrol ability of strain PCL1171.}

The Tn5luxAB transposon library of PCL1171 phase I was used to screen for genes involved in the antagonistic activity of PCL1171 towards G. graminis pv. tritici. A total of 2,000 mutants were screened for the loss of antagonistic activity in an antifungal plate assay (Geels and Schippers 1983). This screening only included mutants expressing phase I morphology with a phase variation frequency comparable to PCL1171. Four mutants, selected for the loss of antagonistic activity, were genetically characterized by sequencing the regions flanking the Tn5luxAB transposon. These sequences revealed that the transposon of all mutants had inserted in a lipopeptide synthetase homologue but in different domains of this gene (Guenzi et al. 1998). The partially sequenced gene product showed highest homology to a syringomycin synthetase (GenBank accession number AF47828). Domains in this gene include adenylation, thiolation, and condensation domains, which are all needed to incorporate a single amino acid in the lipopeptide (Marahiel et al. 1997). Sequencing of the flanking regions of the transposon insertion in PCL1656 (2574 bp surrounding the Tn5 with $75 \%$ identity and $64 \%$ similarity at the amino acid level), PCL1660 (942 bp surrounding the $\mathrm{Tn} 5$ with $75 \%$ identity and $71 \%$ similarity at the amino acid level), PCL1663 (783 bp surrounding the Tn5 with $62 \%$ identity and 53\% similarity at the amino acid level), PCL1666 (1,947 bp surrounding the Tn5 with 50\% identity and $60 \%$ similarity at the amino acid level) showed highest homology to thiolation, adenylation, and condensation domains and a region preceding an adenylation domain, respectively, of lipodepsipeptide synthetase of $P$. syringae pv. syringae. In contrast to wild-type strain phase I cells, mutant PCL1666 phase I cells tested in the G. graminis pv. tritici-wheat system did not result in biocontrol (Fig. 5A).

\section{Role of phase variation genes in biocontrol.}

The PCL1171 mutant derivatives PCL1572 (gacS::Tn5luxAB) and PCL1555 (mutS::Tn5luxAB) were tested in biocontrol. Neither of the mutants showed significant biocontrol activity (Fig. 5B and C). Complementation of PCL1572 and PCL1555 using pMP6562 and pMCS5-mutS, respectively, resulted in restoration of the wild-type colony phase I phenotype (Fig. 1F) as well as in corresponding levels of disease suppression (Fig. 5B and C).

\section{DISCUSSION}

\section{Isolation and preliminary characterization of antagonistic} Pseudomonas spp. strains that undergo phase variation.

Performance of biocontrol microorganisms in the field is variable. Elucidation of the mechanism behind this phenomenon will contribute to defining the traits required for robust biocontrol strains and, therefore, enhanced performance. Our group has found that phase variation mediated by the $\mathrm{xerC/sss}$ gene has a profound effect on a Pseudomonas strain's ability for competitive root colonization (Dekkers et al. 1998, 2000) and biocontrol (Chin-A-Woeng et al. 2000). We therefore initiated a study on phase variation among Pseudomonas rhizosphere strains with the aim to identify other genes and traits involved in phase variation.

Maize in Totontepec Mixe, Mexico has been grown successfully for over 700 years without the application of chemicals. Since the climate in this region is warm and humid, conditions are ideal for the proliferation of fungi. A possible explanation for the excellent yields of maize could be a high incidence of biocontrol microbes protecting the plants against diseases caused by pathogenic fungi. Therefore, microbes derived from the maize rhizosphere of plants from this region were investigated. From 214 isolated putative Pseudomonas strains, 46 isolates $(21 \%)$ were found to inhibit the growth of a number of important crop pathogens including G. graminis pv. tritici, which causes wheat take-all, and $F$. oxysporum f. sp. radicislycopersici, which causes tomato foot and root rot. Indeed, this frequency of biocontrol strains is extremely high. For comparison, we previously found that the frequency of biocontrol pseudomonads in the rhizosphere of tomatoes from a commercial agricultural field in Andalusia (Spain) is approximately 1\% (Chin-A-Woeng et al. 1998).

A striking phenomenon was that 43 out of the 46 antagonistic isolates showed reversible colony phase variation (Fig. 1B and $\mathrm{C}$ ). The reversible character of the colony phase variation is illustrated by the occurrence of phase II sectors originating from phase I colonies (Fig. 1B) and phase I sectors originating from phase II colonies (Fig. 1C). We selected 15 clearly different strains and tested these to determine the influence of phase variation on other biocontrol traits and found that the production of such diverse metabolites as antifungal metabolite, chitinase, biosurfactant, protease, and lipase are subject to phase variation. The majority of these molecules are synthesized by the opaque phase I colony form but not by the translucent form (Table 2). Other differences between these colony forms were found in motility (Fig. 3) and cell surface proteins (Fig. 2). It should be noted that the difference in motility may be caused by the effect of phase variation on biosurfactant production, since biosurfactant can influence motility by enabling bacteria to break the colony boundary more easily, resulting in irregular swimming (Mendelson and Salhi 1996).

Since the majority of the factors mentioned in Table 2 are synthesized in opaque phase I cells under control of the gac system, it is likely that the factor determining opacity of phase I colonies is under the same control. Consistent with this notion is the finding that opacity proteins (opa genes) in Neisseria gonorrhoeae are also regulated by phase variation (Stern et al. 1986). Therefore, it is conceivable that one or more of the cell surface proteins that are relatively strongly expressed in phase I colonies (Fig. 2) are determining the colony opacity. It should also be realized that, if a strain does not produce this opacity factor, phase variation may occur but may not be visible as a change in colony morphology.

\section{Genetic characterization of colony phase variation of PCL1171.}

One of the 15 strains, Pseudomonas sp. strain PCL1171, was chosen for a preliminary genetic characterization of colony phase variation. Since phase I colony morphology is dominant in PCL1171 (Fig. 1A), mutants locked in phase II (Fig. 1D) can be detected relatively easily. Both of the analyzed phase II-locked mutants appeared to have the transposon inserted in a gacS homologue (Fig. 4A). GacS is the sensor kinase of a two-component regulatory system that, in combination with the response regulator GacA, controls the production of a wide range of secondary metabolites (Whistler et al. 1998), including the production of AFM, chitinase, protease, $\mathrm{HCN}$, and virulence factors (Laville et al. 1992; Mahajan et al. 1999). The gacS/gacA regulatory system belongs to the FixJ family of transcriptional regulators (Laville et al. 1992). Our results indicate that the gacA/gacS system is one of the key players in phase variation, since mutation of $g a c S$ locks the bacteria in phase II. This is supported by the complementation by gacS and gacA of spontaneous phase II bacteria from wild-type strains PCL1157, PCL1182, and PCL1184. 
Recent reports on $\mathrm{gacA} / \mathrm{gacS}$ have shown that both genes are targets of point mutations, small deletions, and insertions. For example, $P$. fluorescens grown in nutrient rich liquid media to stationary phase accumulates spontaneous stable gacA and gacS mutants (Bull et al. 2001). Furthermore, a homologue of gacS, the pheN gene of $P$. tolaasii, was shown to be regulated by phase variation through an internal 661-bp duplication (Han et al. 1997). Bull and associates (2001) reported a selective advantage under laboratory conditions for the loss of gacA function, which might represent another example of phase variation via $g a c A / g a c S$. In addition, Chancey and associates (2002) reported that gacA/gacS mutants can survive in the rhizosphere and, when present in wild-type populations, will increase the survival of these mixed populations. Also, in this case, phase variation could be the cause of these mixed populations. It is therefore conceivable that, in the heterogeneous and changing microenvironment of the rhizosphere, the ability to adapt by changing the expression of specific traits to reduce metabolic load via gacA/gacS, combined with the beneficial effect of these mutants on population survival in the rhizosphere, could be advantageous for the bacterium.

Mutant PCL1555 shows a strongly increased frequency of switching between phases I and II (Fig. 1E). Genetic analysis showed that its transposon is inserted into a homologue of the $m u t S$ gene (Fig. 4B). MutS is involved in methyl-directed recognition of DNA mismatches related to replication. MutS recognizes base mismatches and small insertions or deletion mispairs originating from replication. Upon recognition of these mismatches by MutS, a repair pathway involving MutLH is activated, resulting in excision of the mismatch by exonucleases. Strand specificity in excision and resynthesis of the excised strand is determined by the hemimethylated state of the DNA (Modrich 1991). Mutation of mutS is reported to result in the persistence of mutations due to the lack of repair (Campoy et al. 2000). For example, mutation of the mutS gene resulted in a 100- to 1,000-fold increase in the frequency of mutations found in E. coli (Horst et al. 1999). Whereas our results strongly suggest that the $\mathrm{gacA} / \mathrm{gacS}$ system is a key regulator in colony phase variation, we hypothesize that the high frequency of phase variation in mutS mutant PCL1555 is the result of the lack of repair of mutations in the gacA and gacS genes. Considering the data obtained for our gacS and mutS mutants, we hypothesize that introduction of mutations in gacA/gacS is the basis for the phase I to phase II switch. It is likely that the reverse switch from phase II to phase I is based on repair of these mutations in $g a c A / g a c S$ and is likely to involve $m u t S$.

\section{Effect of colony phase variation on biocontrol ability of strain PCL1171.}

It appeared that PCL1171 phase I cells but not phase II cells are active as a biocontrol agent of wheat take-all (Fig. 5). The activity of phase I cells of PCL1171 is even slightly better than that of the well-known tomato foot and root rot biocontrol strain P. chlororaphis PCL1391 (Fig. 5A) (Chin-A-Woeng et al. 1998). This is the first report that shows that strain PCL1391 also controls a disease of a monocot plant. The gacS mutant PCL1572, which exhibits only phase II morphology (Fig. 1D), is as inactive in biocontrol as phase II wild-type cells (Fig. 5B). Both phase I colony appearance and biocontrol activity by the mutant (Fig. 5B) are restored by genetic complementation. In conclusion, there exists a strong correlation between phase I and biocontrol ability. These results show that PCL1171 requires a functional Gac system for efficient biocontrol of wheat take-all. Previously, it was shown that a gacA mutant of $P$. fluorescens $\mathrm{CHAO}$ exhibited biocontrol in a Ggt system, presumably due to the (up-regulated) production of siderophores, which is not dependent on GacA (SchmidliSacherer et al. 1997). Also, mutS mutant PCL1555 is impaired in biocontrol and, in this case, this phenomenon can be restored by genetic complementation (Fig. 5C). Possible advantageous effects of a high mutation rate on the fitness of cells are short-term effects. In contrast, in the long term, especially in heterogeneous environments, a high mutation rate will reduce the overall fitness due to the high mutation load (Giraud et al. 2001). It is therefore conceivable that the high mutation frequency in mutant PCL1555 leads to a higher percentage of disabled cells, which are poorly rhizosphere-competent and, therefore, will hardly contribute to biocontrol.

\section{Role of antagonism \\ in biocontrol ability of strain PCL1171.}

Mutant PCL1666 lacks antagonistic activity (Fig. 5A) but is still expressing a wild-type phase I morphology. Genetic analysis of this mutant showed that its transposon is inserted in a homologue of a lipopeptide synthetase gene. This gene has been described as being responsible for the production of a lipodepsipeptide (Bender et al. 1999; Guenzi et al. 1998). Some lipopeptides are known as host-specific toxins that play an important role in the virulence of, for example, $P$. syringae (Bender et al. 1999). In this context, it should be stressed that PCL1171 phase I cells, tested in a biocontrol experiment in the absence of G. graminis pv. tritici, did not cause disease symptoms on wheat (data not shown). The lack of antagonistic activity of mutant PCL1666 (Fig. 5A) is consistent with published data showing that a number of lipopeptides, including syringomycin, can have fungicidal activity (Bender et al. 1999; Thrane et al. 2000). Based on our observations, we conclude that the production of the antifungal metabolite of PCL1171 is a prerequisite for the biocontrol activity of this strain. The genetic analysis of PCL1666 strongly suggests that the mutation resides in the structural gene for a lipopeptide that is switched off in phase II and that this is one of the reasons for the lack of biocontrol activity of this phase variant (Fig. 5A). This hypothesis is supported by the observation that both the phase switch in strain PCL1171 as well as the production of a variety of toxins by P. syringae (Barta et al. 1992) and lipopeptide production in Pseudomonas sp. strain DSS73 (Koch et al. 2002) are dependent on gacS activity.

We have shown that Pseudomonas sp. strain PCL1171 can control wheat take-all and that one of the important biocontrol traits is the production of an AFM (Fig. 5A), likely to be a lipopeptide in nature. Since phase variation may be a frequently occurring phenomenon that hampers the optimal production of the AFM of PCL1171 as well as optimal colonization and biocontrol of P. chlororaphis PCL1391 (Chin-AWoeng et al. 2000; Dekkers et al. 1998), phase variation may be a major factor in the inconsistent biocontrol observed in several field trails (Schippers et al. 1987; Weller 1988). Thus, phase variation not only plays a role in escaping animal and human defense by enabling pathogens to adapt to heterogeneous or hostile environments (LeClerc and Cebula 2000; Rosengarten and Wise 1990) but it also appears to play a vital and much broader role in the ecology of bacteria producing exoenzymes, antibiotics, and other secondary metabolites.

We plan to investigate the genetic basis of phase variation in more detail in order to determine which traits are involved in regulation of phase variation and which target genes are regulated by it. Hopefully, this research will result in more insight about traits required for robustness of biocontrol strains. The result may also be of importance for the efficient production of industrial enzymes, such as protease and lipase, and of antibiotics and biosurfactants. Similarly, since vaccines frequently contain cell surface proteins of which the synthesis can be 
under control of phase variation, an enhanced control of phase variation may be used to more efficiently produce purer and less expensive vaccines.

\section{MATERIALS AND METHODS}

Microbial strains and plasmids.

Bacterial strains and plasmids are listed in Table 1. Pseudomonas strains were grown on $\mathrm{KB}$ (King et al. 1954) at $28^{\circ} \mathrm{C}$. Solid growth media contained 1.8\% (wt/vol) agar (Difco Laboratories, Detroit). Kanamycin, gentamicin, tetracycline, and cyclohexamide (Sigma, St. Louis) were added for antibiotic selection in final concentrations of 50,10, 40, and $100 \mu \mathrm{g} / \mathrm{ml}$, respectively, when appropriate. Fungi were grown on KB or potato dextrose agar (Difco Laboratories). BM (minimal basic medium) (Lugtenberg et al. 2001) with $0.2 \%$ glycerol as carbon source was used for screening for mutants without antagonistic activity.

For the isolation of Pseudomonas strains from the rhizosphere, roots from maize plants were shaken twice for $30 \mathrm{~min}$ in phosphate buffered saline (PBS) (Sambrook et al. 1989). The resulting suspensions were plated and grown overnight in Pseudomonas isolation medium (Difco Laboratories) at $28^{\circ} \mathrm{C}$. Colony morphology and ARDRA (Vaneechoutte et al. 1998) were used to identify the strains and select Pseudomonas spp.

For strain identification of PCL1171 phase I and phase II, colony PCR (Williams et al. 1990) was used for amplification of the 16S rDNA from colonies with a phase I or phase II morphology. The PCR products were sequenced by BaseClear (Leiden, The Netherlands) or ServiceXS (Leiden, the Netherlands) and analyzed for homologies using BLAST (Altschul et al. 1997).

\section{Measurement of phase variation frequencies.}

Bacteria with a phase I or phase II morphology were inoculated in a volume of $5 \mathrm{ml}$ of $\mathrm{KB}$ to an optical density at $620 \mathrm{~nm}$ $\left(\mathrm{OD}_{620}\right)$ of 0.05 and were grown shaking overnight at $28^{\circ} \mathrm{C}$. By measuring the optical density and subsequent dilution and plating on $\mathrm{KB}$ medium, an average of 500 colonies per plate was obtained. For estimation of frequencies, at least 1,500 colonies were counted. To obtain the frequency of switching, the number of switches was divided by the number of generations passed.

\section{Construction, selection, and complementation of mutants.}

A mutant library of strain PCL1171 phase I was constructed using the plasmid pRL1063a, which harbors a Tn5 transposon with promotorless $\operatorname{lu} x A B$ genes and a kanamycin resistance marker (Wolk et al. 1991). Electro-competent phase I cells were obtained by scraping the cells from the plates and washing them three times with sterile water, followed by two washings with $10 \%$ glycerol. pRL1063a plasmid DNA (1 to $2 \mu \mathrm{g}$ ) was used for electroporation of electro-competent cells using a pulsar device (settings: $25 \mu \mathrm{F}, 100 \Omega$, and $2.5 \mathrm{kV}$ ) (BioRad Lab, Richmond, CA, U.S.A.). The transformation mixture was grown in SOB medium (Sambrook et al. 1989) for $2 \mathrm{~h}$ and, subsequently, plated on selective medium and grown at $28^{\circ} \mathrm{C}$. The obtained transposons were judged after at least 2 days of growth on $\mathrm{KB}$ plates for altered colony morphology. Mutants lacking colony phase variation or showing an increased frequency of colony phase variation were selected. Furthermore, mutants expressing a phase I morphology but that had lost their antagonistic activity were selected, using BM agar plates on which eight mutants were grown surrounding an inoculum of the fungus G. graminis pv. tritici (Geels and Schippers 1983). Mutants unable to inhibit the fungus were selected after 7 days of growth.

DNA regions flanking the transposon were isolated by excision of the transposon from the chromosomal DNA of the transposons using EcoRI or ClaI, followed by ligation and transformation with $E$. coli strain DH5 $\alpha$. Since the Tn5 transposon harbors an origin of replication (p15A), the plasmid can replicate and maintain itself in $E$. coli. The plasmids were reisolated. The flanking chromosomal regions were sequenced using unique primers oMP458 (5'-TACTAGATTCAATGCTATCAATTGAG-3') and oMP459 (5'-AGGAGGTCACATGGAATATCAGAT-3') directed outwards of the transposon ends. Sequencing was carried out by BaseClear (Leiden, The Netherlands) or ServiceXS (Leiden, The Netherlands). General DNA modification techniques were performed according to Sambrook and associates (1989).

\section{Complementation of the gacS mutant strains.}

Primers oMP658 (5'-GGAATTCAGGATGTCCATCAACA CCA-3') and oMP618 (5'-GGAATTCATCGTTGATGAAGGC ACACA-3') were used to amplify the complete gacS gene from PCL1171 by PCR. The obtained PCR fragment was cloned into pGEMTeasy (Promega Corp., Madison, WI, U.S.A.) and was subsequently cloned in pME6010 using EcoRI. This construct, pMP6562, was used to transform PCL1563 and PCL1572 by electroporation. In addition, phase II bacteria of wild-type strains PCL1157, PCL1182, and PCL1184 were complemented using pMP6562, and pMP5565 by mating.

Analysis of cell envelope proteins and lipopolysaccharides.

To analyze LPS and membrane protein patterns, cells with a specific phase I or phase II morphology were harvested separately from plate after 2 days of growth at $28^{\circ} \mathrm{C}$ and were resuspended in $50 \mathrm{mM}$ Tris- $\mathrm{HCl}, 2 \mathrm{mM}$ EDTA, $\mathrm{pH}$ 8.5. To isolate cell envelopes, cells were sonicated and centrifuged for 20 $\min$ at 2,700 rpm and for $1 \mathrm{~h}$ at $10,000 \mathrm{rpm}$ to isolate preparations for the analysis of LPS and total membrane proteins, respectively. The obtained pellets were resuspended and stored in CE-buffer (2 mM Tris-HCl, pH 7.8). To visualize LPS patterns, the cell envelope preparation was incubated for $15 \mathrm{~min}$ at $100^{\circ} \mathrm{C}$ in $125 \mathrm{mM}$ Tris/ $\mathrm{HCl}, \mathrm{pH} 6.8,4.0 \%$ SDS, $20 \%$ glycerol, and $0.02 \%$ bromophenol blue, followed by proteinase $\mathrm{K}$ treatment. The LPS fractions were separated in a denaturing $11 \%$ SDS-PAGE gel using a Mini-Protean 3 Cell system (BioRad $\mathrm{Lab}$ ). The LPS pattern was visualized by silver staining (Tsai and Frasch 1982). Cell envelope proteins were denatured by adding $\beta$-mercaptoethanol to the cell envelope mixture to a final concentration of $0.1 \%$, followed by incubation for 10 minutes at $100^{\circ} \mathrm{C}$. Proteins were separated on an $11 \%$ SDSPAGE denaturing gel using a mini-protean 3 cell system (Bio$\mathrm{Rad} \mathrm{Lab}$ ) and were visualized with Coomassie blue staining (Sambrook et al. 1989).

\section{Analysis of biocontrol traits.}

Antagonistic activity against the fungi Fusarium oxysporum f. sp. radicis-lycopersici, Rhizoctonia solani, Rosellinia necatrix, and G. graminis pv. tritici was analyzed, using an agar plate on which the fungus was inoculated in the center of a petri dish, whereas four bacterial strains were spot-inoculated at a distance of 2 to $3 \mathrm{~cm}$. After 7 days of growth at $28^{\circ} \mathrm{C}$, the plates were examined for growth inhibition zones of the fungus surrounding the bacterial spot (Geels and Schippers 1983).

For the detection of secreted bacterial protease, $\beta$-glucanase, lipase, and cellulase, $1.8 \%$ agar plates containing 5\% skim milk, 0.1\% lichenan (Sigma) (Walsh et al. 1995), 2\% Tween 80 (Howe and Ward 1976), or $0.5 \%$ carboxymethylcellulose (Hankin and Anagnostakis 1977) were used, respectively. The plates were inspected for degradation zones as judged by clearing or precipitation zones in case of lipase activity, after 5 days of growth at $28^{\circ} \mathrm{C}$. 
For the detection of secreted chitinase activity chitinpentaose (Seikagaku, Tokyo) was $O$-acelytated with ${ }^{14} \mathrm{C}$-acetyl CoA (Amersham Life Sciences, Cleveland, OH, U.S.A.), using the $O$-acetyl transferase NodL, as described by Bloemberg and associates (1994). Samples consisting of cell-free supernatant fluid of overnight cultures were loaded on a $\mathrm{NH}_{2} \mathrm{~F}_{245 \mathrm{~s}}$ thin layer chromatography plate (Merck, Darmstadt, Germany) and chromatographed, using a $65 \%$ acetonitril $/ 35 \%$ water (vol/vol) mixture. The distribution, e.g. breakdown, of chitinpentaose of radioactivity was measured after 4 to 7 days of exposure, using a phosphor imager (BioRad Lab).

Hydrogen cyanide was detected by growing the bacterial strains on agar plates in the presence of $3 \mathrm{MM}$ paper $(2 \times 2 \mathrm{~cm})$ drenched in a solution of copper(II) ethyl-acetoacetate (5 $\mathrm{mg} / \mathrm{ml})$ and 4,4'-methylene-bis-(N,N-dimethylaniline) (5 $\mathrm{mg} / \mathrm{ml}$ ) (Castric 1975). Hydrogen cyanide turns the indicator paper blueish purple.

Production of biosurfactant was determined using a dropcollapsing assay, in which a small amount of bacteria was taken from a bacterial colony with a toothpick and resuspended in 15 to $30 \mu \mathrm{l}$ drops of water placed on parafilm. The presence of biosurfactant decreases the surface tension and, therefore, results in the collapse of the drop (Jain et al. 1991).

Bacteria were tested for motility after spot inoculating of cells in the middle of a plate containing $1 / 20 \mathrm{~KB}$ solidified with $0.3 \%$ agar. The plates were examined for the presence of migration zones after overnight incubation at $28^{\circ} \mathrm{C}$ (Dekkers et al. 1998).

\section{Attachment assays.}

For root attachment experiments, tomato seeds were sterilized by incubating the seeds for $3 \mathrm{~min}$ in 5\% sodium hypochlorite, followed by five rinses for $25 \mathrm{~min}$ in $20 \mathrm{ml}$ of sterile water. Subsequently, the seeds were incubated for $3 \mathrm{~min}$ in $70 \%$ ethanol, followed by five rinses with sterile water. After a second incubation for $1 \mathrm{~h}$ in $5 \%$ sodium hypochlorite, the fluid was removed, and the seeds were left for $1 \mathrm{~h}$ in sterile water. The latter procedure was repeated once. Sterilized wheat and tomato seeds were stored on PNS (Hoffland et al. 1989) agar plates at $4^{\circ} \mathrm{C}$ and were allowed to germinate on PNS agar at $28^{\circ} \mathrm{C}$. Seedlings were grown in a PNS solution in magenta vessels (Sigma, Bornhem, Belgium) holding a perforated stainless steel tray for 7 days at $20^{\circ} \mathrm{C}$. Bacteria scraped from agar plates were resuspended in PBS to an $\mathrm{OD}_{620}=1.0$. The roots were incubated for $45 \mathrm{~min}$ in the bacterial suspension, were removed, and were washed in PBS to remove all nonattached bacteria. The roots were shaken vigorously for $15 \mathrm{~min}$ in a suspension of PBS in the presence of sand, in an Eppendorf shaker (Eppendorf, Hamburg, Germany) to remove attached bacteria from the root. Appropriate dilutions of the suspensions were plated on $\mathrm{KB}$ agar. The number of colonies was determined after 2 days of growth at $28^{\circ} \mathrm{C}$.

\section{Biocontrol of take-all of wheat caused by G. graminis pv. tritici.}

The G. graminis pv. tritici-wheat system as described by Weller and associates (1985) was used to test biocontrol activity. Briefly, an inoculum was prepared by growing G. graminis pv. tritici on sterilized oat for 3 to 4 weeks. The inoculum was dried overnight in a flow cabinet and was stored at $4^{\circ} \mathrm{C}$. The inoculum for the biocontrol assay was prepared following the method of Weller and associates (1985). A bacterial suspension $\left(2 \times 10^{9} \mathrm{CFU} / \mathrm{ml}\right)$ and a $2.0 \%(\mathrm{wt} / \mathrm{vol})$ methylcellulose solution were mixed (1:1 vol/vol) and used to coat wheat seeds (Triticum aestivum cultivar Residence). Wheat seeds were sown (nine seeds per pot) on a mixture of potting soil and chemically pure sand, in a 1:1 ratio containing a predetermined percentage of inoculum that results in 60 to $80 \%$ diseased plants, and were covered with approximately $1 \mathrm{~cm}$ of inoculum-free potting soil. After 2 to 3 weeks of growth at $15^{\circ} \mathrm{C}$, the number of diseased plants was determined based on the characteristic disease symptoms of take-all (Raaijmakers and Weller 1998). Plants were scored as diseased or healthy.

\section{ACKNOWLEDGMENTS}

The majority of this research is supported by the Technology Foundation Stichting voor de Technische Wetenschappen, Applied Science Division of Nederlands organisatie voor Wetenschappelijk Onderzoek, and the Technology Programme of the Ministry of Economic Affairs (LBI.4792). K. Eijkemans was supported by ALW/NWO project grant 811.35.003. The authors would like to thank B. Hallberg for his valuable discussions and his kind help in visiting Totontepac Mixe, J. Raaymakers for his guidance in setting up the Gaeumannomyces graminis pv. tritici wheat biocontrol system, H.-V. Tichy for the ARDRA analysis, and J. L. Barra for supplying us with plasmid pMCS5-mutS.

\section{LITERATURE CITED}

Abraham, J. M., Freitag, C. S., Clements, J. R., and Eisenstein, B. I 1985. An invertible element of DNA controls phase variation of type 1 fimbriae of Escherichia coli. Proc. Natl. Acad. Sci. U.S.A. 82:57245727.

Altschul, S. F., Madden, T. L., Schaffer, A. A., Zhang, J., Zhang, Z., Miller, W., and Lipman, D. J. 1997. Gapped BLAST and PSI-BLAST: a new generation of protein database search programs. Nucleic Acids Res. 25:3389-3402.

Barta, T. M., Kinscherf, T. G., and Willis, D. K. 1992. Regulation of tabtoxin production by the lemA gene in Pseudomonas syringae. J Bacteriol 174:3021-3029.

Bender, C. L., Alarcon, C. F., and Gross, D. C. 1999. Pseudomonas syringae phytotoxins: Mode of action, regulation, and biosynthesis by peptide and polyketide synthetases. Microbiol. Mol. Biol. Rev. 63:266-292.

Bloemberg, G. V., Thomas-Oates, J. E., Lugtenberg, B. J. J., and Spaink, H. P. 1994. Nodulation protein NodL of Rhizobium leguminosarum $O$ acetylates lipo-oligosaccharides, chitin fragments and $\mathrm{N}$-acetylglucosamine in vitro. Mol. Microbiol. 11:793-804.

Boyer, H. W. and Roulland-Dussoix, D. 1996. A complementation analysis of the restriction and modification of DNA in Escherichia coli. J. Mol. Biol. 41:459-472

Buchenauer, H. 1998. Biological control of soil-borne diseases by rhizobacteria. Z. Pflanzenkrankh Pflanzenschutz 105:329-348.

Bull, C. T., Duffy, B., Voisard, C., Defago, G., Keel, C., and Haas, D. 2001. Characterization of spontaneous gacS and gacA regulatory mutants of Pseudomonas fluorescens biocontrol strain CHAO. Antonie Van Leeuwenhoek 79:327-336.

Campoy, S., de Rozas, A. M. P., Barbe, J., and Badiola, I. 2000. Virulence and mutation rates of Salmonella typhimurium strains with increased mutagenic strength in a mouse model. FEMS (Fed. Eur. Microbiol. Soc.) Lett. 187:145-150.

Castric, P. A. 1975. Hydrogen cyanide, a secondary metabolite of Pseudomonas aeruginosa. Can. J. Microbiol. 21:613-618.

Chabeaud, P., de Groot, A., Bitter, W., Tommassen, J., Heulin, T., and Achouak, W. 2001. Phase-variable expression of an operon encoding extracellular alkaline protease, a serine protease homolog, and lipase in Pseudomonas brassicacearum. J. Bacteriol. 183:2117-2120.

Chancey, S. T., Wood, D. W., Pierson, E. A., and Pierson, L. S., III. 2002. Survival of GacS/GacA mutants of the biological control bacterium Pseudomonas aureofaciens 30-84 in the wheat rhizosphere. Appl. Environ. Microbiol. 68:3308-3314.

Chin-A-Woeng, T. F. C., Bloemberg, G. V., Mulders, I. H. M., Dekkers, L. C., and Lugtenberg, B. J. J. 2000. Root colonization by phenazine1-carboxamide-producing bacterium Pseudomonas chlororaphis PCL1391 is essential for biocontrol of tomato foot and root rot. Mol. Plant-Microbe Interact. 13:1340-1345.

Chin-A-Woeng, T. F. C., Bloemberg, G. V., van der Bij, A. J., van der Drift, K. M. G. M., Schripsema, J., Kroon, B., Scheffer, R. J., Keel, C., Bakker, P. A. H. M., Tichy, H.-V., de Bruijn, F. J., Thomas-Oates, J. E., and Lugtenberg, B. J. J. 1998. Biocontrol by phenazine-1-carboxamide-producing Pseudomonas chlororaphis PCL1391 of tomato root rot caused by Fusarium oxysporum f. sp. radicis-lycopersici. Mol. Plant-Microbe Interact. 11:1069-1077.

Colloms, S. D., Sykora, P., Szatmari, G., and Sherratt, D. J. 1990. Recombination at ColE1 cer requires the Escherichia coli xerC gene product, a member of the lambda integrase family of site-specific recombinase. J. Bacteriol. 172:6973-6980. 
Dekkers, L. C., Mulders, I. H., Phoelich, C. C., Chin-A-Woeng, T. F. C. Wijfjes, A. H., and Lugtenberg, B. J. J. 2000. The sss colonization gene of the tomato-Fusarium oxysporum $\mathrm{f}$. $\mathrm{sp}$. radicis-lycopersici biocontrol strain Pseudomonas fluorescens WCS365 can improve root colonization of other wild-type Pseudomonas spp. bacteria. Mol. Plant-Microbe Interact. 13:1177-1183.

Dekkers, L. C., Phoelich, C. C., van der Fits, L., and Lugtenberg, B. J. J. 1998. A site-specific recombinase is required for competitive root colonization by Pseudomonas fluorescens WCS365. Proc. Natl. Acad. Sci. U.S.A. 95:7051-7056.

Dunlap, C., Moënne-Loccoz, Y., McCarthy, J., Higgins, P., Powell, J., Dowling, D. N., and O'Gara, F. 1998. Combining proteolytic and phloroglucinol-producing bacteria for improved biocontrol of $P y$ thium-mediated damping-off of sugar beet. Plant Pathol. 47:299-307.

Dybvig, K. 1993. DNA rearrangements and phenotypic switching in prokaryotes. Mol. Microbiol. 10:465-471.

Geels, F. P., and Schippers, G. 1983. Selection of antagonistic fluorescent Pseudomonas spp. and their root colonization and persistence following treatment of seed potatoes. Phytopathol. Z. 108:193-206.

Giraud, A., Radman, M., Matic, I., and Taddei, F.2001. The rise and fall of mutator bacteria. Curr. Opin. Microbiol. 4:582-585.

Guenzi, E., Galli, G., Grgurina, I., Gross, D. C., and Grandi, G. 1998 Characterization of the syringomycin synthetase gene cluster. A link between prokaryotic and eukaryotic peptide synthetases. J. Biol. Chem. 273:32857-32863.

Han, B., Pain, A., and Johnstone, K. 1997. Spontaneous duplication of a 661-bp element within a two-component sensor regulator gene causes phenotypic switching in colonies of Pseudomonas tolaasii, cause of brown blotch disease of mushrooms. Mol. Microbiol. 25:211-218.

Hankin, L., and Anagnostakis, S. L. 1977. Solid media containing carboxymethylcellulose to detect $\mathrm{CX}$ cellulose activity of micro-organisms. J. Gen. Microbiol. 98:109-115.

Heeb, S., Itoh, Y., Nishijyo, T., Schnider, U., Keel, C., Wade, J., Walsh, U., O'Gara, F., and Haas, D. 2000. Small, stable shuttle vectors based on the minimal pVS1 replicon for use in gram-negative, plant-associated bacteria. Mol. Plant-Microbe Interact. 13:232-237.

Henderson, I. R., Owen, P., and Nataro, J. P. 1999. Molecular switches-the ON and OFF of bacterial phase variation. Mol. Microbiol. 33:919-932.

Hoffland, E., Findenbegg, G. R., and Nelemans, E. J. 1989. Solubilization of rock phosphate by rape. Plant Soil 113:161-165.

Horst, J. P., Wu, T. H., and Marinus, M. G. 1999. Escherichia coli mutator genes. Trends Microbiol. 7:29-36.

Howe, T. R., and Ward, J. M. 1976. The utilization of Tween 80 as carbon source by Pseudomonas. J. Gen. Microbiol. 92:234-235

Jain, D. K., Thomson, D. K. C., Lee, H., and Trevors, J. T. 1991. A dropcollapsing test for screening surfactant producing organisms. J. Microbiol. Methods 13:271-279.

Josenhans, C., Eaton, K. A., Thevenot, T., and Suerbaum, S. 2000 Switching of flagellar motility in Helicobacter pylori by reversible length variation of a short homopolymeric sequence repeat in $f l i P$, a gene encoding a basal body protein. Infect. Immun. 68:4598-4603.

Keel, C., Wirthner, P., Oberhänsli, T., Voisard, C., Haas, D., and Défago, G. 1990. Pseudomonads as antagonists of plant pathogens in the rhizosphere: Role of the antibiotic 2,4-diacetylphloroglucinol in the suppression of black root of tobacco. Symbiosis 9:327-341.

King, E. O., Ward, M. K., and Raney, D. E. 1954. Two simple media for the demonstration of pyocyanin and fluorescein. J. Lab. Clin. Med. 44:301-307.

Koch, B., Nielsen, T. H., Sorensen, D., Andersen, J. B., Christophersen, C., Molin, S., Givskov, M., Sorensen, J., and Nybroe, O. 2002. Lipopeptide production in Pseudomonas sp. strain DSS73 is regulated by components of sugar beet seed exudate via the Gac two-component regulatory system. Appl. Environ. Microbiol. 68:4509-4516.

Laville, J., Voisard, C., Keel, C., Maurhofer, M., Défago, G., and Haas, D. 1992. Global control in Pseudomonas fluorescens mediating antibiotic synthesis and suppression of black root rot of tobacco. Proc. Natl. Acad. Sci. U.S.A. 89:1562-1566.

LeClerc, J. E., and Cebula, T. A. 2000. Pseudomonas survival strategies in cystic fibrosis. Science 289:391-392.

Leong, J. 1986. Siderophores: Their biochemistry and possible role in the biocontrol of plant pathogens. Annu. Rev. Phytopathol. 24:187-209.

Lugtenberg, B. J. J., Dekkers, L. C., and Bloemberg, G. V. 2001. Molecular determinants of rhizosphere colonization by Pseudomonas. Annu. Rev. Phytopathol. 39:461-490.

Mahajan, M. S., Tan, M. W., Rahme, L. G., and Ausubel, F. M. 1999. Molecular mechanisms of bacterial virulence elucidated using a $\mathrm{Pseu}$ domonas aeruginosa-Caenorhabditis elegans pathogenesis model. Cell 96:47-56.

Marahiel, M. A., Stachelhaus, T., and Mootz, H. D. 1997. Modular peptide synthetases involved in nonribosomal peptide synthesis. Chem.
Rev. 97:2651-2674.

Maurhofer, M., Keel, C., and Défago, G. 1994. Pyoluteorin production by Pseudomonas fluorescens strain CHA0 is involved in the suppression of Pythium damping-off of cress but not of cucumber. Eur. J. Plant Pathol. 100:221-232.

Mendelson, N. H., and Salhi, B. 1996. Patterns of reporter gene expression in the phase diagram of Bacillus subtilis colony forms. J. Bacteriol. 178:1980-1989.

Meyer, T. F., Gibbs, C. P., and Haas, R. 1990. Variation and control of protein expression in Neisseria. Annu. Rev. Microbiol. 44:451-477.

Modrich, P. 1991. Mechanisms and biological effects of mismatch repair Annu. Rev. Genet 25:229-253.

Pérez-Jiménez, R. M. 1997. Podredumbres radiculares del aguacate (Persea americana Mill) en el sur de Andalucia. Ph.D. thesis, University of Malaga, Spain.

Pezza, R. J., Smania, A. M., Barra, J. L., and Argarana, C. E. 2002. Nucleotides and heteroduplex DNA preserve the active conformation of Pseudomonas aeruginosa MutS by preventing protein oligomerization. Biochem. J. 361:87-95.

Raaijmakers, J. M., and Weller, D. M. 1998. Natural plant protection by 2,4-diacetylphloroglucinol-producing Pseudomonas spp. in take-all decline soils. Mol. Plant-Microbe Interact. 11:144-152.

Rosengarten, R., and Wise, K. S. 1990. Phenotypic switching in mycoplasmas: phase variation of diverse surface lipoproteins. Science 247:315-318.

Sambrook, J., Fritsch, E. F., and Maniatis, T. 1989. Molecular Cloning: A Laboratory Manual. Cold Spring Harbor Laboratory Press, Cold Spring Harbor, NY, U.S.A.

Schippers, B., Bakker, A. W., and Bakker, P. A. H. M. 1987. Interactions of deleterious and beneficial rhizosphere microorganisms and the effect of cropping practices. Annu. Rev. Phytopathol. 25:339-358.

Schmidli-Sacherer, P., Keel, C., and Defago, G. 1997. The global regulator GacA of Pseudomonas fluorescens $\mathrm{CHAO}$ is required for suppression of root diseases in dicotyledons but not in Gramineae. Plant Pathol. 46:80-90.

Stanghellini, M. E., and Miller, R. M. 1997. Biosurfactants. Their identity and potential efficacy in the biological control of zoosporic plan pathogens. Plant Dis. 81:4-12.

Stern, A., Brown, M., Nickel, P., and Meyer, T. F. 1986. Opacity genes in Neisseria gonorrhoeae: Control of phase and antigenic variation. Cell 47:61-71.

Thomashow, L. S., and Weller, D. M. 1988. Role of a phenazine antibiotic from Pseudomonas fluorescens in biological control of Gaeumannomyces graminis var. tritici. J. Bacteriol. 170:3499-3508.

Thrane, C., Harder, N. T., Neiendam, N. M., Sorensen, J., and Olsson, S. 2000. Viscosinamide-producing Pseudomonas fluorescens DR54 exerts a biocontrol effect on Pythium ultimum in sugar beet rhizosphere. FEMS (Fed. Eur. Microbiol. Soc.) Ecol. 33:139-146.

Trejo, E. S. R., Paszczynski, A., and Crawford, D. L. 1998. Antibiotics and enzymes produced by the biocontrol agent Streptomyces violaceusniger YCED-9. J. Ind. Microbiol. Biotechnol. 21:81-90.

Tsai, C. M., and Frasch, C. E. 1982. A sensitive silver stain for detecting lipopolysaccharides in polyacrylamide gels. Anal. Biochem. 119:115119.

Vaneechoutte, M., Boerlin, P., Tichy, H.-V., Bannerman, E., Jager, B., and Bille, J. 1998. Comparison of PCR-based DNA fingerprinting techniques for the identification of Listeria species and their use for atypical Listeria isolates. Int. J. Syst. Bacteriol. 48:127-139.

Voisard, C., Keel, C., Haas, D., and Defago, G. 1989. Cyanide production by Pseudomonas fluorescens helps suppress black root rot of tobacco under gnotobiotic conditions. EMBO (Eur. Mol. Biol. Organ.) J. 8:351-358.

Walsh, G. A., Murphy, R. A., Killeen, G. F., Headon, D. R., and Power, R. F 1995. Technical note: Detection and quantification of supplemental fungal $\beta$-glucanase activity in animal feed. J. Anim. Sci. 73:1074-1076.

Weller, D. M. 1988. Biological control of soilborne plant pathogens in the rhizosphere with bacteria. Annu. Rev. Phytopathol. 26:379-407.

Weller, D. M., Zhang, B. X., and Cook, R. J. 1985. Application of a rapid screening test for selection of bacteria suppressive to take-all of wheat. Plant Dis. 69:710-713.

Whistler, C. A., Corbell, N. A., Sarniguet, A., Ream, W., and Loper, J. E. 1998. The two-component regulators GacS and GacA influence accumulation of the stationary-phase sigma factor sigma(S) and the stress response in Pseudomonas fluorescens Pf-5. J. Bacteriol. 180:6635-6641.

Williams, J. G., Kubelik, A. R., Livak, K. J., Rafalski, J. A., and Tingey, S. V. 1990. DNA polymorphisms amplified by arbitrary primers are useful as genetic markers. Nucleic Acids Res. 18:6531-6535.

Wolk, C. P., Cai, Y., and Panoff, J. M. 1991. Use of a transposon with luciferase as a reporter to identify environmentally responsive genes in a cyanobacterium. Proc. Natl. Acad. Sci. U.S.A. 88:5355-5359. 